\title{
SIMILARITY OF SLOVAK REGIONS IN NEOPLASTIC MORTALITY IN THE CONTEXT OF RISK FACTORS AND ACCESS TO HEALTH CARE
}

\author{
Beáta Gavurová ${ }^{1}$, Boris Popesko², Janusz K. Grabara 3 , Samuel Koróny ${ }^{4}$ \\ ${ }^{1}$ Faculty of Economics, Technical University of Košice, Košice, Slovak Republic \\ ${ }^{2}$ Faculty of Management and Economics, Tomas Bata University in Zlín, Zlín, Czech Republic \\ ${ }^{3}$ Faculty of Management, Czestochowa University of Technology, Czestochowa, Poland \\ ${ }^{4}$ Research and Innovation Centre, Faculty of Economics, Matej Bel University, Banská Bystrica, Slovak Republic
}

\section{SUMMARY}

Aim: Access to primary health care is highly connected to the prevention of cancer mortality, since the risk factors threatening health can be early identified. The aim of this paper is, firstly, to explore similarity within and between the regions of the Slovak Republic and cancer mortality patterns, and secondly, to reveal if similar regions are characterised by the similar access to health care or risk factors occurrence.

Methods: Data on deaths by sex, type of cancer death and region from 1996 to 2014 is provided by the National Health Information Centre of Slovakia. The relationships between 8 regions and 16 cancer types are described by correspondence analysis for both sexes.

Results: The most similar cancer mortality patterns among Slovak regions are between the Nitra and Trnava regions for both sexes, and the Košice region for males. The Prešov region is showed as an outlier from other regions for females, likely due to the highest concentration of Roma marginalised communities. As for access to health care, the Trnava region as well as Nitra region report the lowest densities of physicians, 2.4 and 2.6 per 1,000 inhabitants, respectively. The most serious cancer types mortality is attributed to the digestive organs (C15-C26) in each Slovak region for both sexes with the average proportion of 35.56\%. Observed high association between the Nitra region and respiratory cancer (C30C39) in males may be confirmed by the increased incidence of radon in this region. Similarly, a tight relationship between the Bratislava region and cancer of male genital organs (C60-C63) can relate to the highest proportion of drug users in the Bratislava region.

Conclusions: Based on the findings of similar regions in cancer mortality patterns, we recommend to set the same prevention programs in the Trnava and Nitra regions, on the other hand, different preventive interventions should be introduced in the Prešov region.

Key words: cancer types mortality, correspondence analysis, Slovak regions

Address for correspondence: S. Koróny, Research and Innovation Centre, Faculty of Economics, Matej Bel University, Cesta na amfiteáter 1 , 97401 Banská Bystrica, Slovak Republic. E-mail: samuel.korony@umb.sk

https://doi.org/10.21101/cejph.a5051

\section{INTRODUCTION}

Due to different types of geographic locations in the Slovak Republic or unequal medical decisions based on socio-economic characteristics of patients, it may grow disparities in the delivery of health care services. Subsequently, these are reflected in the diverse morbidity and mortality patterns from various diseases across countries or even within small-areas. The aim of any health policy should be to increase access to health care in terms of geographic distribution of health care services focusing on primary prevention of chronic diseases, such as cancer that causes the second largest amounts of deaths worldwide and also in the Slovak Republic (1-4).

\section{Geographic Distribution of Primary Health Care}

Geographic distribution of primary health care reflects the number of physicians per 1,000 inhabitants according to the classification of territorial units NUTS II or NUTS III and the density of physicians in urban or rural areas. Based on NUTS III classification, Slovakia is divided into the 8 regions with the number of inhabitants considering status in middle period 2004 from time interval 1996 to 2014: Bratislava region $(600,277)$, Trnava region $(552,624)$, Trenčín region $(601,722)$, Banská Bystrica region (658,753), Košice region (770,112), Nitra region $(709,414)$, Prešov region $(795,848)$, Žilina region $(693,824)$. The density of physicians is conveniently greater in urban regions (6.7 per 1,000 inhabitants) compared to rural regions (2.6 per 1,000 inhabitants) in the Slovak Republic. Differences in the number of general practitioners according to NUTS II are as follows: Bratislava region (6.6 per 1,000 inhabitants), Western Slovakia (2.5), Central Slovakia (2.9) and Eastern Slovakia (3.3) (5). Under the Slovak Government Regulation No.640/2008 Coll., the minimum network of healthcare providers in each individual medical field was defined in order to meet the demand for health care services (6).

WHO survey (7) notes, there were not reported significant regional differences in the provision of primary health care by 
general practitioners in Slovakia, however, recognises significant differences between the various districts of the region. For example, analysis of the situation in Banská Bystrica region revealed large differences in the number of patients pertaining to one practitioner, what may indicate a relative lack of practitioners in some areas. The density of doctors per 1,000 inhabitants in individual regions of Slovakia (NUTS III) is as follows: Bratislava (6.6), Trnava (2.4), Trenčín (2.5), Nitra (2.6), Žilina (3.2), Banská Bystrica (2.6), Prešov (2.7), Košice (3.9) (8). Consequently, Bratislava region has an average of 1.7 to 2.8 times larger number of doctors than other regions of Slovakia. However, only well educated and motivated physicians caution their patients to be careful about risk factors that significantly affect cancer mortality.

\section{Cancer Mortality and Risk Factors}

Although significant advances have been made in the fight against cancer, it remains a key public health item after cardiovascular diseases and a considerable burden on societies across the European countries (9). In 2012, more than one and a quarter million residents of the EU-28 died from cancer, just 26\% of all deaths. In Slovakia, the share of deaths from cancer in the total number of deaths reached 24.6\%: among men this share was around $27.3 \%$, while among women it was $21.9 \%$. In Slovakia, the average standardised mortality of cancer rates for men (472 per 100,000 European standard population) is around twice higher than for women (229 per 100,000 European standard population) during the past two decades (10).

Many factors determine cancer mortality patterns, mostly uncontrollable ones, such as genetics, age and sex, as well as controllable ones, such as social, economic, environmental factors, lifestyle, smoking, obesity, alcohol consumption may also play an important role (11).

Unfortunately, data on the majority of cancer risk factors is not available at the regional level in Slovakia, such as alcohol consumption, smoking, fruit and vegetable consumption. However, there are some determinants that can be specified for the Slovak regions.

The evidence shows that drugs, such as methamphetamine, heroin, cannabis, contain hundreds of harmful chemicals that cause many types of cancer, mostly of the lungs, head, neck, and respiratory tract (12-14). Cannabis use increases the risk of testicular cancer, especially in younger people (15). In 2014, the highest proportion of patients undergoing treatment of drug abuse by permanent address was in Bratislava (115.3 per 100,000 inhabitants) and Trnava (69.3) regions and the lowest in Prešov region (10.9). Trenčín, Nitra and Žilina regions reported an average of 42.2 abused people per 100,000 inhabitants, Košice and Banská Bystrica showed 31 on average (16). It is seemed that rate of drug users has been increasing from Eastern Slovakia to Western Slovakia.

Similarly, the increased risk of death from cancer is raising from environmental factors. One of the main risk factors relating to the environment is radon, as a natural radioactive gas, which gets into the respiratory system by breathing and causes tissue damage, with consequent formation of lung cancer (17-20). The rate of radon risk in individual regions of Slovakia is determined by their geological structures, as well as the presence of uranium deposit in their territory. Slovak territories with low and high radon risk were specified in the Ministry of Health Decree no. 406/1992 Coll. on requirements for limiting exposure to radon and other natural radionuclides (21). Areas with medium or high risk of radon levels include the following districts and their corresponding regions: Šal'a district, Topolčany, Zlaté Moravce (Nitra region); Bánovce nad Bebravou district and Púchov (Trenčín region); Bytča district (Žilina region), Pezinok district (Bratislava region). Košice region and Prešov region are assigned among the areas with a higher occurrence of uranium.

Age is one of the out of controlled variables influencing mortality. Since 1996, a sharp increase in an average percentage share of cancer deaths has been observed in people aged from 30 to 74 in each Slovak region. After age 75 , shares continually have fallen (16). There are not significant age differences in cancer mortality across regions. On the other hand, the ageing index, expressed as the ratio of post-productive population (65+ age group) and preproductive age population (0-14 age group) multiplied by 100 , supposes a higher mortality at older ages in these three regions: Trenčín region (115.3), Nitra region (113.94), Trnava (103.18) (16). It should be keep in mind, that ageing index consider all cause mortality, not only cancer mortality.

The aim of this study is to reveal similarity between regions of the Slovak Republic and mortality from the specific cancer types, and subsequently to determine similar characteristics pertaining to these regions. It may serve as a base for setting prevention programs aimed at the most common groups of cancer and endangered region.

\section{MATERIALS AND METHODS}

Source of data on deaths by sex, type of cancer death and region from 1996 to 2014 is provided by National Health Information Centre in Slovakia. Main analytical method in our paper is correspondence analysis. Its goal is to describe the relationships between two categorical variables in a cross table in a low-dimensional space. For each variable, the distances between category points in a plot reflect the relationships between the categories with similar categories plotted close to each other. Projecting points for one variable on the vector from the origin to a category point for the other variable describe the relationship between the variables. Factor analysis or principal components are standard techniques for describing relationships between variables in a low-dimensional space. However, they require interval data, and the number of observations should be at least five times the number of variables. Correspondence analysis, on the other hand, assumes nominal variables and can describe the relationships between categories of each variable, as well as the relationship between the variables.

Graphical result of correspondence analysis is so called correspondence map that depicts relative positions of rows and columns of cross table. Table rows (in our case - groups of cancer types) which are close together in correspondence map are similar from viewpoint of their proportions in table columns (in our case - Slovak regions). In our case we have got cross-table with 16 rows and 8 columns. The objective of correspondence analysis is to project both rows and columns of cross table to two dimensional plane and preserve as much information as possible about positions of groups of cancer types in original 16 dimensional space of rows 
and about positions of Slovak regions in original 8 dimensional space of columns. Quality of correspondence analysis is measured by relative amount of so called "inertia" (similar to explained variance in regression). Statistical software IBM SPSS version 19 was used for the analysis. Our assumption is that age structure was similar in all Slovak regions so it was not necessary to standardize counts. From official population data of Statistical Office of the Slovak Rerpublic it is clear that proportions in corresponding age intervals differ by only one or two percent among regions. It means relative differences among regions are negligible.

\section{RESULTS}

The results section is divided according to sex as a one of the basic biosocial characteristics of deceased. If we look at the Table 1 of original counts for females, then it is difficult to make any conclusions about similarity of cancer types according to their counts in Slovak regions. And vice versa, what can be said about similarity of Slovak regions from the viewpoint of cancer types? That is the reason, why correspondence analysis is applied.

Groups of cancer types together with corresponding Slovak regions are depicted in Figure 1 of correspondence map.

First axis explains $37.95 \%$ of the inertia of the true proportions, the second one $22.81 \%$ (total $60.76 \%$ ). So we can make some (at least qualitative) statements about original positions of both diagnoses and regions. We can see that diagnosis C97 (Malignant neoplasms with multiple primary outbreaks in various locations) as initial death cause is adjacent. Similarly, other groups of diagnoses are different: C30-C39 (Malignant neoplasms of respiratory and intrathoracic organs), D37-D48 (Neoplasms of uncertain or unknown behaviour), D10-D36 (Benign neoplasms), C40C41 (Malignant neoplasms of bone and articular cartilage) and
C45-C49 (Malignant neoplasms of mesothelial and soft tissue). Their position is far away from the rest of cancer initial causes of death. If we look at the Table 2 of diagnoses row proportions in Slovak regions, we can see why above mentioned diagnoses groups are different.

In last row of Table 2 we can see average row proportions in separate regions. They are the proportions in regions in all cancer types. Extreme values (minimums and maximums) are marked as bold. Overall, the smallest proportion of cancer types is in Trenčín region (10.84\%). The largest one is in Nitra region (15.64\%).

Let us start with C97 (Malignant neoplasms with multiple primary outbreaks in various locations). It is the only one diagnosis with the largest proportion in Trenčín region (19.31\%) and the smallest proportion in Prešov region (6.07\%). Group C30-C39 (Malignant neoplasms of respiratory and intrathoracic organs) has got the largest proportion in Košice region (16.47\%) and the smallest one in Prešov region (9.28\%). Neoplasms of uncertain or unknown behaviour (D37-D48) have got the largest proportion in Žilina region (17.10\%) and the smallest one in Banská Bystrica region (7.76\%). Last adjacent group is C40-C41 (Malignant neoplasms of bone and articular cartilage). It has got the largest proportion in Prešov region (16.71\%). The smallest one is in Trenčín region (8.23\%). Last outstanding diagnoses are C45-C49 (Malignant neoplasms of mesothelial and soft tissue). They have got the largest proportion in Košice region (15.14\%) while the smallest proportion is in Trnava region (9.19\%).

The other diagnoses groups have got extreme proportions in several and the same regions. In Trenčín region with the smallest proportions and Nitra region with the largest proportions there are following diagnoses: C00-C14 (Malignant neoplasms of lip, oral cavity and pharynx), C15-C26 (Malignant neoplasms of digestive organs), C69-C72 (Malignant neoplasms of eye, brain and other parts of central nervous system), C76-C80 (Malignant

Table 1. Cross table of absolute death counts caused by neoplastic diseases types in Slovak regions, women

\begin{tabular}{|l|c|c|c|c|c|c|c|c|c|}
\hline \multirow{2}{*}{ CD } & \multicolumn{9}{|c|}{ Region } \\
\cline { 2 - 11 } & Bratislava & Trnava & Trenčín & Nitra & Žilina & B. Bystrica & Prešov & Košice & Total \\
\hline C00-C14 & 147 & 141 & 137 & 239 & 145 & 182 & 143 & 167 & 1,301 \\
\hline C15-C26 & 4,382 & 3,759 & 3,668 & 5,479 & 3,946 & 4,054 & 3,945 & 4,563 & 33,796 \\
\hline C30-C39 & 1,273 & 871 & 841 & 1,250 & 850 & 1,185 & 784 & 1,391 & 8,445 \\
\hline C40-C41 & 42 & 42 & 34 & 59 & 54 & 59 & 69 & 54 & 413 \\
\hline C43-C44 & 246 & 184 & 186 & 285 & 232 & 295 & 219 & 239 & 1,886 \\
\hline C45-C49 & 129 & 85 & 107 & 113 & 103 & 114 & 134 & 140 & 925 \\
\hline C50 & 2,224 & 1,725 & 1,640 & 2,357 & 1,675 & 1,842 & 1,482 & 1,885 & 14,830 \\
\hline C51-C58 & 1,942 & 1,626 & 1,631 & 2,329 & 1,702 & 1,879 & 1,683 & 1,989 & 14,781 \\
\hline C64-C68 & 584 & 490 & 456 & 529 & 483 & 508 & 491 & 501 & 4,042 \\
\hline C69-C72 & 391 & 345 & 342 & 479 & 395 & 391 & 397 & 425 & 3,165 \\
\hline C73-C75 & 78 & 59 & 67 & 90 & 86 & 84 & 79 & 74 & 617 \\
\hline C76-C80 & 368 & 268 & 236 & 470 & 329 & 256 & 271 & 247 & 2,445 \\
\hline C81-C96 & 894 & 726 & 718 & 949 & 862 & 860 & 856 & 864 & 6,729 \\
\hline C97 & 67 & 85 & 140 & 107 & 127 & 62 & 44 & 93 & 725 \\
\hline D10-D36 & 36 & 32 & 22 & 35 & 28 & 23 & 46 & 28 & 250 \\
\hline D37-D48 & 110 & 65 & 77 & 93 & 119 & 54 & 98 & 80 & 696 \\
\hline Total & 12,913 & 10,503 & 10,302 & 14,863 & 11,136 & 11,848 & 10,741 & 12,740 & 95,046 \\
\hline
\end{tabular}


Table 2. Row proportions (in \%) of death counts caused by neoplastic diseases types in Slovak regions, women

\begin{tabular}{|c|c|c|c|c|c|c|c|c|}
\hline \multirow{2}{*}{ ICD } & \multicolumn{8}{|c|}{ Region } \\
\hline & Bratislava & Trnava & Trenčín & Nitra & Žilina & B. Bystrica & Prešov & Košice \\
\hline C00-C14 & 11.30 & 10.84 & 10.53 & 18.37 & 11.15 & 13.99 & 10.99 & 12.84 \\
\hline C15-C26 & 12.97 & 11.12 & 10.85 & 16.21 & 11.68 & 12.00 & 11.67 & 13.50 \\
\hline С30-С39 & 15.07 & 10.31 & 9.96 & 14.80 & 10.07 & 14.03 & 9.28 & 16.47 \\
\hline C40-C41 & 10.17 & 10.17 & 8.23 & 14.29 & 13.08 & 14.29 & 16.71 & 13.08 \\
\hline C43-C44 & 13.04 & 9.76 & 9.86 & 15.11 & 12.30 & 15.64 & 11.61 & 12.67 \\
\hline C45-C49 & 13.95 & 9.19 & 11.57 & 12.22 & 11.14 & 12.32 & 14.49 & 15.14 \\
\hline C50 & 15.00 & 11.63 & 11.06 & 15.89 & 11.29 & 12.42 & 9.99 & 12.71 \\
\hline C51-C58 & 13.14 & 11.00 & 11.03 & 15.76 & 11.51 & 12.71 & 11.39 & 13.46 \\
\hline C64-C68 & 14.45 & 12.12 & 11.28 & 13.09 & 11.95 & 12.57 & 12.15 & 12.39 \\
\hline C69-C72 & 12.35 & 10.90 & 10.81 & 15.13 & 12.48 & 12.35 & 12.54 & 13.43 \\
\hline C73-C75 & 12.64 & 9.56 & 10.86 & 14.59 & 13.94 & 13.61 & 12.80 & 11.99 \\
\hline C76-C80 & 15.05 & 10.96 & 9.65 & 19.22 & 13.46 & 10.47 & 11.08 & 10.10 \\
\hline C81-C96 & 13.29 & 10.79 & 10.67 & 14.10 & 12.81 & 12.78 & 12.72 & 12.84 \\
\hline C97 & 9.24 & 11.72 & 19.31 & 14.76 & 17.52 & 8.55 & 6.07 & 12.83 \\
\hline D10-D36 & 14.40 & 12.80 & 8.80 & 14.00 & 11.20 & 9.20 & 18.40 & 11.20 \\
\hline D37-D48 & 15.80 & 9.34 & 11.06 & 13.36 & 17.10 & 7.76 & 14.08 & 11.49 \\
\hline Total & 13.59 & 11.05 & 10.84 & 15.64 & 11.72 & 12.47 & 11.30 & 13.40 \\
\hline
\end{tabular}

neoplasms of ill-defined, secondary and unspecified sites) and C81-C96 (Malignant neoplasms, stated or presumed to be primary, of lymphoid, haematopoietic and related tissue). So they are similar from this viewpoint and that is why they are near together in correspondence map.

If we look for Slovak regions at correspondence map (Fig. 1) we see that Prešov region is far away from other regions. At the Table 3 of column proportions we see that all regions have got the largest proportions in group C15-C26 (Malignant neoplasms of digestive organs). Average total proportion is $35.56 \%$. All other regions have got the smallest proportion in group D10D36 (Benign neoplasms) with average total proportion equal to

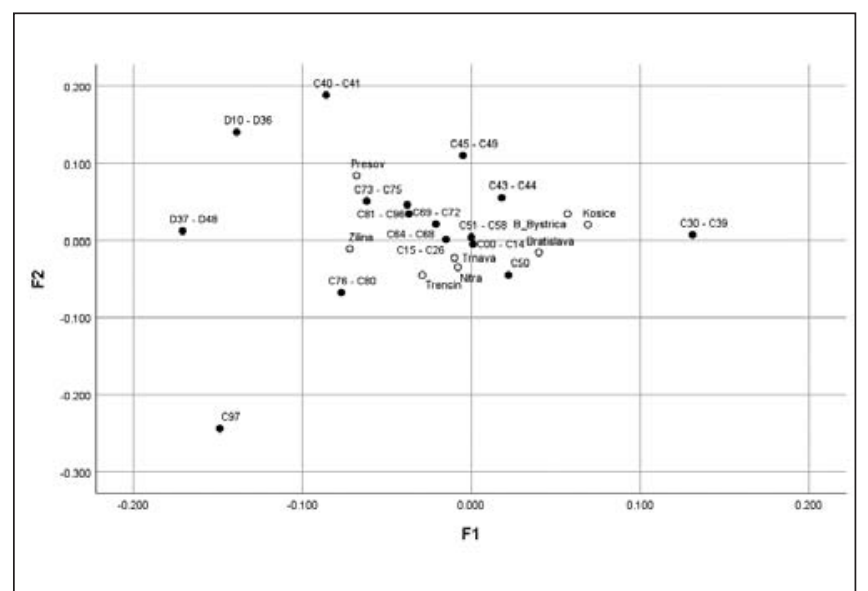

Fig.1. Correspondence map of female cancer mortality in groups of cancer types in Slovak regions.
0.26\%, except Prešov region. Prešov region is the only one with the smallest proportion in group C97 (Malignant neoplasms of independent (primary) multiple sites). Two most similar regions are Trnava and Nitra and they are closely associated with the cancer mortality from C00-C14 (Malignant neoplasms of lip, oral cavity and pharynx), C15-C26 (Malignant neoplasms of digestive organs), C51-C58 (Malignant neoplasms of female genital organs). Another couple of similar regions is Banská Bystrica and Košice that are a little bit associated with C30-C39 (Malignant neoplasms of respiratory and intrathoracic organs) and C43-C44 (Melanoma and other malignant neoplasms of skin).

Counts of male death from the individual cancer types are depicts in Table 4. Again, this cross table of counts is not sufficient for analysing similarity of Slovak regions.

Male cancer types together with corresponding Slovak regions are depicted in Figure 2 of correspondence map. First axis explains $41.03 \%$ of the inertia of the true proportions, the second one $21.95 \%$ (total $62.98 \%$ ). Again, we can see that cancer types C97 (Malignant neoplasms with multiple primary outbreaks in various locations), C40-C41 (Malignant neoplasms of bone and articular cartilage) and D10-D36 (Benign neoplasms) are adjacent. Contrary to women, C00-C14 (Malignant neoplasms of lip, oral cavity and pharynx) are also outlying.

Let us look at Table 5 of cancer types of death (row) proportions in Slovak regions to see why above mentioned diagnoses groups are different. The largest total proportion is again in Nitra region (15.30\%). The smallest proportion is in Bratislava region (11.00\%).

As it is in case of women diagnosis C97 (Malignant neoplasms with multiple primary outbreaks in various locations) is the only 
Table 3. Column proportions (in \%) of death counts caused by neoplastic diseases types in Slovak regions, women

\begin{tabular}{|l|c|c|c|c|c|c|c|c|c|}
\hline \multirow{2}{*}{ ICD } & \multicolumn{9}{|c|}{ Region } \\
\cline { 2 - 11 } & Bratislava & Trnava & Trenčín & Nitra & Žilina & B. Bystrica & Prešov & Košice & Total \\
\hline C00-C14 & 1.14 & 1.34 & 1.33 & 1.61 & 1.30 & 1.54 & 1.33 & 1.31 & 1.37 \\
\hline C15-C26 & 33.93 & 35.79 & 35.60 & 36.86 & 35.43 & 34.22 & 36.73 & 35.82 & 35.56 \\
\hline C30-C39 & 9.86 & 8.29 & 8.16 & 8.41 & 7.63 & 10.00 & 7.30 & 10.92 & 8.89 \\
\hline C40-C41 & 0.33 & 0.40 & 0.33 & 0.40 & 0.48 & 0.50 & 0.64 & 0.42 & 0.43 \\
\hline C43-C44 & 1.91 & 1.75 & 1.81 & 1.92 & 2.08 & 2.49 & 2.04 & 1.88 & 1.98 \\
\hline C45-C49 & 1.00 & 0.81 & 1.04 & 0.76 & 0.92 & 0.96 & 1.25 & 1.10 & 0.97 \\
\hline C50 & 17.22 & 16.42 & 15.92 & 15.86 & 15.04 & 15.55 & 13.80 & 14.80 & 15.60 \\
\hline C51-C58 & 15.04 & 15.48 & 15.83 & 15.67 & 15.28 & 15.86 & 15.67 & 15.61 & 15.55 \\
\hline C64-C68 & 4.52 & 4.67 & 4.43 & 3.56 & 4.34 & 4.29 & 4.57 & 3.93 & 4.25 \\
\hline C69-C72 & 3.03 & 3.28 & 3.32 & 3.22 & 3.55 & 3.30 & 3.70 & 3.34 & 3.33 \\
\hline C73-C75 & 0.60 & 0.56 & 0.65 & 0.61 & 0.77 & 0.71 & 0.74 & 0.58 & 0.65 \\
\hline C76-C80 & 2.85 & 2.55 & 2.29 & 3.16 & 2.95 & 2.16 & 2.52 & 1.94 & 2.57 \\
\hline C81-C96 & 6.92 & 6.91 & 6.97 & 6.38 & 7.74 & 7.26 & 7.97 & 6.78 & 7.08 \\
\hline C97 & 0.52 & 0.81 & 1.36 & 0.72 & 1.14 & 0.52 & 0.41 & 0.73 & 0.76 \\
\hline D10-D36 & 0.28 & 0.30 & 0.21 & 0.24 & 0.25 & 0.19 & 0.43 & 0.22 & 0.26 \\
\hline D37-D48 & 0.85 & 0.62 & 0.75 & 0.63 & 1.07 & 0.46 & 0.91 & 0.63 & 0.73 \\
\hline
\end{tabular}

Table 4. Cross table of absolute death counts caused by neoplastic diseases types in Slovak regions, men

\begin{tabular}{|l|c|c|c|c|c|c|c|c|c|}
\hline \multirow{2}{*}{ ICD } & \multicolumn{9}{|c|}{ Region } \\
\cline { 2 - 10 } & Bratislava & Trnava & Trenčín & Nitra & Žilina & B. Bystrica & Prešov & Košice & Total \\
\hline C00-C14 & 866 & 1,147 & 970 & 1,782 & 1,310 & 1,390 & 1,395 & 1,474 & 10,334 \\
\hline C15-C26 & 5,298 & 5,286 & 5,385 & 7,271 & 5,549 & 5,892 & 5,917 & 6,185 & 46,783 \\
\hline C30-C39 & 3,683 & 4,336 & 3,908 & 5,616 & 4,575 & 4,925 & 4,549 & 5,097 & 36,689 \\
\hline C40-C41 & 36 & 57 & 66 & 89 & 81 & 85 & 75 & 68 & 557 \\
\hline C43-C44 & 287 & 223 & 260 & 294 & 248 & 271 & 244 & 249 & 2,076 \\
\hline C45-C49 & 147 & 103 & 122 & 129 & 100 & 103 & 135 & 137 & 976 \\
\hline C50 & 36 & 24 & 19 & 30 & 26 & 27 & 15 & 20 & 197 \\
\hline C60-C63 & 1,374 & 1,146 & 1,219 & 1,454 & 1,302 & 1,390 & 1,385 & 1,408 & 10,678 \\
\hline C64-C68 & 997 & 905 & 953 & 1,197 & 1,023 & 1,157 & 1,044 & 1,038 & 8,314 \\
\hline C69-C72 & 392 & 391 & 384 & 522 & 420 & 383 & 496 & 554 & 3,542 \\
\hline C73-C75 & 56 & 48 & 47 & 60 & 57 & 52 & 52 & 52 & 424 \\
\hline C76-C80 & 367 & 319 & 312 & 591 & 374 & 346 & 380 & 307 & 2,996 \\
\hline C81-C96 & 872 & 754 & 818 & 1,039 & 1,050 & 960 & 989 & 1,023 & 7,505 \\
\hline C97 & 89 & 115 & 193 & 139 & 151 & 63 & 50 & 147 & 947 \\
\hline D10-D36 & 20 & 18 & 17 & 26 & 22 & 23 & 43 & 19 & 188 \\
\hline D37-D48 & 104 & 76 & 87 & 107 & 156 & 58 & 96 & 73 & 757 \\
\hline Total & 14,624 & 14,948 & 14,760 & 20,346 & 16,444 & 17,125 & 16,865 & 17,851 & 132,963 \\
\hline
\end{tabular}

one with the largest proportion in Trenčín region (20.38\%) and the smallest proportion in Prešov region (5.28\%). Both diagnoses C00-C14 (Malignant neoplasms of lip, oral cavity and pharynx) and C40-C41 (Malignant neoplasms of bone and articular cartilage) have got the largest proportions in Nitra region (17.24\%, resp. 15.98\%). The smallest ones are in Bratislava region (8.38\%, resp. 6.46\%). Last adjacent diagnoses group D10-D36 (Benign ne- oplasms) has got the largest proportion in Prešov region (22.87\%) and the smallest one in Trenčín region (9.04\%). C50 (Malignant neoplasm of breast) reports the largest proportion in Bratislava region (18.27\%) and the smallest one in Prešov region (7.61\%).

Let us look for Slovak regions at Table 6 of column proportions. We see that all regions have got the largest proportions in group C15-C26 (Malignant neoplasms of digestive organs) and the 


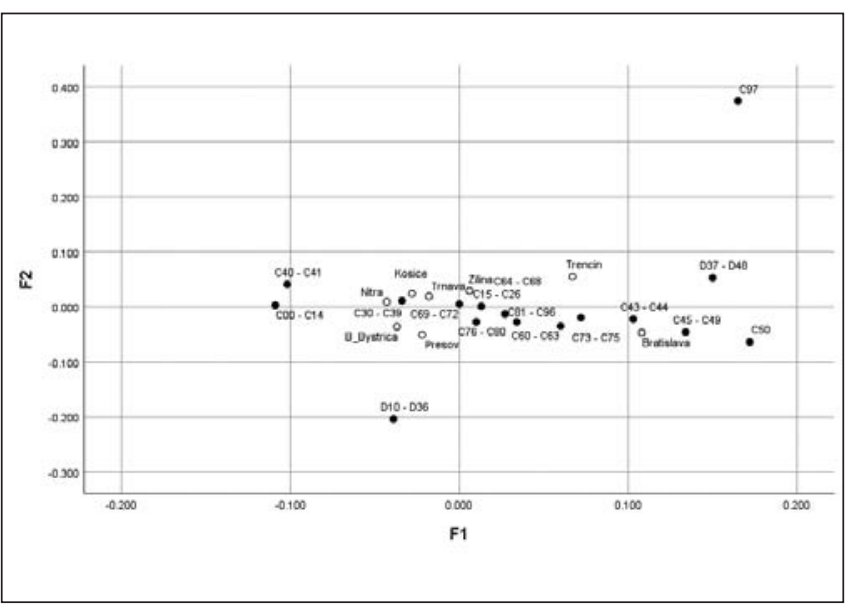

Fig. 2. Correspondence map of male cancer mortality in groups of cancer types in Slovak regions.

smallest ones are in case of group D10-D36 (Benign neoplasms) with the exception of Prešov region with the smallest proportion in group C50 (Malignant neoplasm of breast).

The most similar regions are Košice, Nitra and Trnava. These regions are tight associated with C30-C39 (Malignant neoplasms of respiratory and intrathoracic organs). Deaths from C43-C44 (Melanoma and other malignant neoplasms of skin) and C45-C49 (Malignant neoplasms of mesothelial and soft tissue) are situated closest to Bratislava region what indicate higher occurence of these causes of cancer deaths in Bratislava region than in other regions.

\section{DISCUSSION}

For both sexes, C97 (Malignant neoplasms of independent primary multiple sites), C40-C41 (Malignant neoplasms of bone and articular cartilage) and D10-D36 (Benign neoplasms) have the most unequal distributions across regions. They represent some extremes whose determinants should be explored in the future, with the aim to reveal reasons why they are outliers. In females, we found that Trenčín region captures the most counts of the smallest proportions of cancer types compared to other regions. Surprisingly, cancer type C97 (Malignant neoplasms of independent primary multiple sites) which is outlier from other types takes the highest proportion (19.31\%) just in Trenčín region. For comparison, the lowest proportion of C97 is only 6.07\%, namely in Prešov region. Health policy interventions should be focused on this divergence. Principally, why have deaths from $\mathrm{C} 97$ the highest proportion in Trenčín region? Moreover, C97 holds the highest proportion in Trenčín region also in males.

Prešov region seems to be outlier compared to other regions for females. It may be caused by high concentration of Roma marginalised communities whose health behaviours differ from the rest population in Slovakia, what ultimately leads to the different mortality patterns (22-25). On the other hand, Bratislava region is an outlier for male cancer deaths.

The most serious cancer types mortality is attributed to the digestive organs in each Slovak region for both sexes. Necessarily, neoplasms of digestive organs have to become a priority in introducing prevention programs in Slovakia.

Table 5. Row proportions (in \%) of death counts caused by neoplastic diseases types in Slovak regions, men

\begin{tabular}{|c|c|c|c|c|c|c|c|c|}
\hline \multirow{2}{*}{ ICD } & \multicolumn{8}{|c|}{ Region } \\
\hline & Bratislava & Trnava & Trenčín & Nitra & Žilina & B. Bystrica & Prešov & Košice \\
\hline C00-C14 & 8.38 & 11.10 & 9.39 & 17.24 & 12.68 & 13.45 & 13.50 & 14.26 \\
\hline C15-C26 & 11.32 & 11.30 & 11.51 & 15.54 & 11.86 & 12.59 & 12.65 & 13.22 \\
\hline С30-С39 & 10.04 & 11.82 & 10.65 & 15.31 & 12.47 & 13.42 & 12.40 & 13.89 \\
\hline C40-C41 & 6.46 & 10.23 & 11.85 & 15.98 & 14.54 & 15.26 & 13.46 & 12.21 \\
\hline C43-C44 & 13.82 & 10.74 & 12.52 & 14.16 & 11.95 & 13.05 & 11.75 & 11.99 \\
\hline C45-C49 & 15.06 & 10.55 & 12.50 & 13.22 & 10.25 & 10.55 & 13.83 & 14.04 \\
\hline C50 & 18.27 & 12.18 & 9.64 & 15.23 & 13.20 & 13.71 & 7.61 & 10.15 \\
\hline C60-C63 & 12.87 & 10.73 & 11.42 & 13.62 & 12.19 & 13.02 & 12.97 & 13.19 \\
\hline C64-C68 & 11.99 & 10.89 & 11.46 & 14.40 & 12.30 & 13.92 & 12.56 & 12.48 \\
\hline C69-C72 & 11.07 & 11.04 & 10.84 & 14.74 & 11.86 & 10.81 & 14.00 & 15.64 \\
\hline C73-C75 & 13.21 & 11.32 & 11.08 & 14.15 & 13.44 & 12.26 & 12.26 & 12.26 \\
\hline C76-C80 & 12.25 & 10.65 & 10.41 & 19.73 & 12.48 & 11.55 & 12.68 & 10.25 \\
\hline C81-C96 & 11.62 & 10.05 & 10.90 & 13.84 & 13.99 & 12.79 & 13.18 & 13.63 \\
\hline C97 & 9.40 & 12.14 & 20.38 & 14.68 & 15.95 & 6.65 & 5.28 & 15.52 \\
\hline D10-D36 & 10.64 & 9.57 & 9.04 & 13.83 & 11.70 & 12.23 & 22.87 & 10.11 \\
\hline D37-D48 & 13.74 & 10.04 & 11.49 & 14.13 & 20.61 & 7.66 & 12.68 & 9.64 \\
\hline Total & 11.00 & 11.24 & 11.10 & 15.30 & 12.37 & 12.88 & 12.68 & 13.43 \\
\hline
\end{tabular}


Table 6. Column proportions (in \%) of death counts caused by neoplastic diseases types in Slovak regions, men

\begin{tabular}{|l|c|c|c|c|c|c|c|c|c|}
\hline \multirow{2}{*}{ CD } & \multicolumn{9}{|c|}{ Region } \\
\cline { 2 - 11 } & Bratislava & Trnava & Trenčín & Nitra & Žilina & B. Bystrica & Prešov & Košice & Total \\
\hline C00-C14 & 5.92 & 7.67 & 6.57 & 8.76 & 7.97 & 8.12 & 8.27 & 8.26 & 7.77 \\
\hline C15-C26 & 36.23 & 35.36 & 36.48 & 35.74 & 33.74 & 34.41 & 35.08 & 34.65 & 35.18 \\
\hline C30-C39 & 25.18 & 29.01 & 26.48 & 27.60 & 27.82 & 28.76 & 26.97 & 28.55 & 27.59 \\
\hline C40-C41 & 0.25 & 0.38 & 0.45 & 0.44 & 0.49 & 0.50 & 0.44 & 0.38 & 0.42 \\
\hline C43-C44 & 1.96 & 1.49 & 1.76 & 1.45 & 1.51 & 1.58 & 1.45 & 1.39 & 1.56 \\
\hline C45-C49 & 1.01 & 0.69 & 0.83 & 0.63 & 0.61 & 0.60 & 0.80 & 0.77 & 0.73 \\
\hline C50 & 0.25 & 0.16 & 0.13 & 0.15 & 0.16 & 0.16 & 0.09 & 0.11 & 0.15 \\
\hline C60-C63 & 9.40 & 7.67 & 8.26 & 7.15 & 7.92 & 8.12 & 8.21 & 7.89 & 8.03 \\
\hline C64-C68 & 6.82 & 6.05 & 6.46 & 5.88 & 6.22 & 6.76 & 6.19 & 5.81 & 6.25 \\
\hline C69-C72 & 2.68 & 2.62 & 2.60 & 2.57 & 2.55 & 2.24 & 2.94 & 3.10 & 2.66 \\
\hline C73-C75 & 0.38 & 0.32 & 0.32 & 0.29 & 0.35 & 0.30 & 0.31 & 0.29 & 0.32 \\
\hline C76-C80 & 2.51 & 2.13 & 2.11 & 2.90 & 2.27 & 2.02 & 2.25 & 1.72 & 2.25 \\
\hline C81-C96 & 5.96 & 5.04 & 5.54 & 5.11 & 6.39 & 5.61 & 5.86 & 5.73 & 5.64 \\
\hline C97 & 0.61 & 0.77 & 1.31 & 0.68 & 0.92 & 0.37 & 0.30 & 0.82 & 0.71 \\
\hline D10-D36 & 0.14 & 0.12 & 0.12 & 0.13 & 0.13 & 0.13 & 0.25 & 0.11 & 0.14 \\
\hline D37-D48 & 0.71 & 0.51 & 0.59 & 0.53 & 0.95 & 0.34 & 0.57 & 0.41 & 0.57 \\
\hline
\end{tabular}

Based on the correspondence map, we state that the most similar regions are Trnava and Nitra regions in female cancer mortality. Primarily, they are associated with the mortality from C00-C14 (Malignant neoplasms of lip, oral cavity and pharynx). Banská Bystrica and Košice regions are also very close each other together with the mortality from C43-C44 (Melanoma and other malignant neoplasms of skin). It is appreciated that there are higher concentration of ultraviolet radiation or solar exposure which influence melanoma skin cancer (26-28). For complex explanation of these causalities, medical analyses would have to be conducted in Slovak regions. As for men, the highest proportion of skin neoplasms is for once concentrated in Bratislava region. The most similar are Košice region, Nitra and Trnava and the most common cancer type is C30-C39 (Malignant neoplasms of respiratory and intrathoracic organs). Especially, a high association between Nitra region and respiratory cancer is confirmed by the increased incidence of radon mentioned in Introduction section. Similarly, we assume that the highest proportion of drug users in Bratislava region may partially explains tight relationship between mortality from C60-C63 (Malignant neoplasms of male genital organs) and Bratislava region (see Fig. 1).

To conclude, we observed that the most similar Slovak regions are Nitra and Trnava for both sexes, additionally Košice region for males. When considering access to health care measured by the density of physicians per 1,000 inhabitants in these regions, we can see that just Nitra region and Trnava region report one of the lowest densities. This can lead to underestimating of primary health care from the patients' perspective.

Our analysis can serve as a basis for creating cancer preventive interventions in each Slovak region separately. Obviously, many educational activities devoting to the prevention programs for cancer risk factors are priorities of health policy in the Slovak Republic, namely Project MONIKA (29), Project CINDI (30), The National Action Plan for the prevention of obesity for the years 2015-2025 (31). Their aim is to ensure effective long-term education of the population on all social levels of society.

Our research was limited mainly in data unavailability. Consideration of higher number of lifestyle factors in each Slovak region, such as alcohol consumption, smoking, diet could provide more detailed and relevant insight on regional cancer mortality issue. As for methods, in our case, two dimensions explain $62 \%$ of inertia. It is questionable, if adding other dimensions would change the strength of associations between regions and cancer types. In spite of mentioned limitations, our paper brings beneficial results in the field of public health.

\section{CONCLUSIONS}

This paper focused on the finding the most similar Slovak regions concerning mortality from cancer types and determining possible risk factors. Our analysis showed that the main interest should be devoted to Nitra region because there is the highest proportion of cancer mortality compared to all cancer deaths in Slovakia for both sexes. Similarly, our main warning about the most serious cancer type relates to the malignant neoplasms of digestive organs.

Due to the potential possibilities of influencing the health status of population in Slovakia, it is necessary to conduct analyses of the factors affecting the deterioration of population's health continuously and to draw conclusions and take action.

\section{Acknowledgements}

This work was supported by the VEGA project No. 1/0945/17 Economic research on quantification of marketing processes aimed at improving value for patient, multidimensional analyses of the marketing mix of healthcare facilities and quantification of their importance in the process of establishment of the system to measure the quality and efficiency in healthcare of the Slovak Republic. 


\section{Conflict of Interests}

None declared

\section{REFERENCES}

1. Stewart BW, Wild CP. World cancer report 2014. Lyon: WHO; 2014.

2. Rečková M, et al. Selected chapters of clinical oncology. Bratislava: ROWEX; 2014. (In Slovak.)

3. Šoltés V, Gavurová B. The possibilities of day surgery system development within the health policy in Slovakia. Health Econ Rev. 2014;4:35. doi:10.1186/s13561-014-0035-1.

4. Šoltés V, Gavurová B. The Functionality comparison of the health care systems by the analytical hierarchy process method. E M Ekon Manag. 2014;17(3):100-17.

5. OECD. Health at a Glance 2013: OECD Indicators [Internet]. Paris: OECD Publishing; 2013 [cited 2016 Feb 5]. Available from: http://www. oecd-ilibrary.org/social-issues-migration-health/health-at-a-glance-2013_ health_glance-2013-en.

6. Decree of the Government of the Slovak Republic No. 640 of 17 December 2008 on a minimal public network of health care providers, as amended. Zbierka zákonov SR [Internet]. 2008 [cited 2016 Apr 5]; Pt 213. Available from: http://www.health.gov.sk/?nariadenia. (In Slovak.)

7. WHO. Evaluation of the structure and provision of primary care in Slovakia [Internet]. WHO; 2012 [cited 2016 Feb 5]. Available from: http:// www.euro.who.int/data/assets/pdf_file/0003/175242/Evaluation-of-thestructure-and-provision-of-primary-care-in-Slovakia.pdf.

8. Zachar D. The health system in the Slovak Republic (2012-2013) [Internet]. INEKO; 2013 [cited 2016 Apr 15]. Available from: http:// www.i-health.sk/analyzy/1435 zdravotnicky-system-v-sr-2012-2013. (In Slovak.)

9. Gavurová B, Vagašová T. Regional differences of standardised mortality rates for ischemic heart diseases in the Slovak Republic for the period 1996-2013 in the context of income inequality. Health Econ Rev. 2016;6:21. doi:10.1186/s13561-016-0099-1.

10. EUROSTAT. Cancer statistics [Internet]. 2013 [cited 2016 May 20]. Available from: http://ec.europa.eu/eurostat/statistics-explained/index. php/Cancer_statistics.

11. EUROSTAT. Eurostat regional yearbook. 2016 edition. Luxembourg: Publications office of the European Union; 2016.

12. Lacson JC, Carroll JD, Tuazon E, Castelao EJ, Bernstein L, Cortessis VK. Population-based case-control study of recreational drug use and testis cancer risk confirms association between marijuana use and nonseminoma risk. Cancer. 2012;118(21):5374-83.

13. Sidney S, Beck JE, Tekawa IS, Quesenberry CP, Friedman GD. Marijuana use and mortality. Am J Public Health. 1997;87(4):585-90.

14. Fugelstad A, Annell A, Rajs J, Agren G. Mortality and causes and manner of death among drug addicts in Stockholm during the period 1981-1992. Acta Psychiatr Scand. 1997;96(3):169-75.

15. Center for Behavioral Health Statistics and Quality. Behavioral health trends in the United States: Results from the 2014 National Survey on Drug Use and Health [Internet]. 2015 [cited 2016 Feb 5]. Available from: http://www.samhsa.gov/data/.

16. Health statistics yearbook of the Slovak Republic 2014. Bratislava: National Health Information Center; 2016. (In Slovak, English.)

17. Hazelton WD, Clements MS, Moolgavkar SH. Multistage carcinogenesis and lung cancer mortality in three cohorts. Cancer Epidemiol Biomarkers Prev. 2005;14(5):1171-81.
18. Heidenreich WF, Wellmann J, Jacob P, Wichmann HE. Mechanistic modelling in large case-control studies of lung cancer risk from smoking. Stat Med. 2002;21:3055-70.

19. Meza R, Hazelton WD, Colditz GA, Moolgavkar SH. Analysis of lung cancer incidence in the Nurses' Health and the Health Professionals' Follow-Up Studies using a multistage carcinogenesis model. Cancer Causes Control. 2008;19(3):317-28.

20. Schöllnberger H, Manuguerra M, Bijwaard H, Boshuizen H, Altenburg HP, Rispens SM, et al. Analysis of epidemiological cohort data on smoking effects and lung cancer with a multi-stage cancer model. Carcinogenesis. $2006 \mathrm{Jul} ; 27(7): 1432-44$.

21. Decree of the Ministry of Health of the Slovak Republik No. 406 of 26 June 1992 on requirements to reduce exposure to radon and other natural radionuclides, as amended. Zbierka zákonov SR [Internet]. 1992 [cited 2016 Apr 5];Pt 82. Available from: http://www.noveaspi.sk/products/ lawText/1/40134/1/2. (In Slovak.)

22. Popper M, et al. Population and health: analysis of the situation in Slovakia. Bratislava: Partners for Democratic Change Slovakia; 2009. (In Slovak.)

23. Hubková B, Tkáčiková S, Guzy J, Mareková M; HEPA-META team. Health of Roma in eastern Slovakia. Individ Soc [Internet]. 2014 [cited 2017 Dec 10];17(1):98-102. Available from: http://www.clovekaspolocnost.sk/jquery/pdf.php?gui=BPVUP9LH4QFFAACQ3Y7F2TWLK. (In Slovak.)

24. Matlovičová K, Matlovič R, Mušinka A, Židová A. The Roma population in Slovakia. Basic characteristics of the Roma population with emphasis on the spatial aspects of its differentiation. In: Penczes J, Radics Z, editors. Roma popuation on the peripheries of the Visegrad countries. Spatial trends and social challenges. Debrecen; 2012. p. 77-104. (In Slovak.)

25. Mušinka A, Kolesárová J. Situation of the Roma in Slovakia and their status in the contemporary Slovak society. Brief outline of the Roma situation and of associated problems. Cent Eur Reg Policy Hum Geograph. 2012;2(2):7-14.

26. Watson M, Holman DM, Maguire-Eisen M. Ultraviolet radiation exposure and its impact on skin cancer risk. Semin Oncol Nurs. 2016;32(3):241-54.

27. Fischer AH, Wang TS, Yenokyan G, Kang S, Chien AL. Association of indoor tanning frequency with risky sun protection practices and skin cancer screening. JAMA Dermatol. 2016 Oct 12. doi: 10.1001/jamadermatol.2016.3754.

28. Fears TR, Sagebiel RW, Halpern A, Elder DE, Holly EA, Guerry D 4th, et al. Sunbeds and sunlamps: who used them and their risk for melanoma. Pigment Cell Melanoma Res. 2011 Jun;24(3):574-81

29. Baráková A, Avdičová M, Čorňák V, Hraška V, et al. Selected data from health statistics of the development of diseases of circulatory system in the Slovak Republic - project MONIKA. Bratislava: State Health Institute; 1999. (In Slovak.)

30. Avdičová M, Egnerová A, Hrubá F. Prevalence of risk factors of cardiovascular diseases: results of the CINDI screening. Banská Bystrica: State Institute of Public Health; 2000.

31. PHASR - Public Health Authority of the Slovak Republic. The National Action Plan for the prevention of obesity for the years 2015-2025 [Internet]. 2015 [cited 2016 May 25]. Available from: http://www.uvzsr.sk/ docs/info/podpora/NAPPO_2015-2025.pdf. (In Slovak.)

Received January 26, 2017 Accepted in revised form December 19, 2017 